\title{
Enhanced Formation of 3-(Methylthio)-1-propanol in a Salt-tolerant Yeast, Zygosaccharomyces rouxii, Due to Deficiency of $S$-Adenosylmethionine Synthase
}

\author{
Terumichi Aoki and Kinji UCHIDA \\ Research and Development Division, Kikkoman Corporation, \\ Noda-shi, Chiba 278, Japan \\ Received February 22, 1991
}

\begin{abstract}
Mutants resistant to L-ethionine, an analogue of methionine, were derived from $Z$ ygosaccharomyces rouxii $\mathrm{MA}^{\mathrm{r}}$ 1. Some of them produced large amounts of 3-(methylthio)-1-propanol (methionol); an important flavor component of soy sauce. One of these mutants, M33, produced 60 -fold as much methionol as the parental strain $\mathrm{MA}^{\mathrm{r}} 1$ in a minimum medium without methionine. The intracellular methionine pool of this mutant was increased 5 -fold. $S$-Adenosylmethionine (SAM) synthase (EC 2.5,1.6) in the mutant was reduced to $45 \%$ of that in the parent and a decrease in intracellular SAM level was also confirmed. The reduction of the SAM level due to the deficiency of SAM synthase, accompanied by derepression of enzymes of the methionine synthetic pathway, was considered to be responsible for the hyper-production of methionol in the mutant.
\end{abstract}

Soy sauce is a fermented soy bean food containing high concentrations of amino acids including methionine (about $10 \mathrm{~mm}$ ) as well as a large amount $(16 \%)$ of $\mathrm{NaCl}$. 3-(Methylthio)-1-propanol (methionol) is one of the most important flavor components in soy sauce $^{1-3)}$ and is produced by the salt-tolerant haploid yeast, Zygosaccharomyces rouxii, during the fermentation process. Generally, methionol is a metabolite from methionine, and it is scarcely produced in media without methionine. Hence the methionol biosynthetic route from methionine was assumed to be what is called the Ehrlich pathway, known for the production of several higher alcohols (fusel oils). ${ }^{1,4)}$

Throughout attempts to control the production of higher alcohols in soy sauce fermentation, ${ }^{5,6)}$ we have established that the production of several higher alcohols by $Z$. rouxii was colsely related to its amino acid metabolism and that it could be enhanced in mutants resistant to analogues of the corresponding amino acids. Methionol-hyper-producing yeast, however, has not been obtained so far. Now an unique strain that produces a large amount of methionol in a medium without methionine was found among our ethionineresistant mutants. In this report, we described the isolation of methionol-hyper-producing mutant and elucidation of the hyper-producing mechanism including estimation of the mutated enzyme.

\section{Materials and Methods}

Organisms. Z. rouxii NISL 3355 (wild strain) was obtained from the Noda Institute for Scientific Research. A methylamine-resistant strain, $\mathrm{MA}^{\mathrm{r}} \mathrm{l}$, was obtained from the wild strain as a mutant decreasing the uptake of ammonium ion. ${ }^{6)}$ Saccharomyces cerevisiae (ATCC4098) was a culture kept in the research division of Kikkoman Corporation.

Media and growth conditions. A basal medium ( $\mathrm{pH}$ 5.2) contained $5 \% \mathrm{NaCl}, 5 \%$ glucose, $0.87 \% \mathrm{~K}_{2} \mathrm{HPO}_{4}$, and $0.2 \%$ Difco nitrogen base without $\left(\mathrm{NH}_{4}\right)_{2} \mathrm{SO}_{4}$ and amino acids. The medium was supplemented with $2 \mathrm{mM}$ L-proline (M.pro-medium) or $10 \mathrm{mM}\left(\mathrm{NH}_{4}\right)_{2} \mathrm{SO}_{4}$ (M.am-medium). Moromi juice medium (MJ-medium) was prepared as an amino acid-rich medium modeled after soy sauce moromi by the method of Kanbe and Uchida, ${ }^{7)}$ except for its $\mathrm{pH}$ ( $\mathrm{pH}$ 5.2). Yeast cells were grown at $30^{\circ} \mathrm{C}$ under static or aerobic conditions using a reciprocal shaker $(120 \mathrm{rpm})$. When $S$. cerevisiae was cultured, $\mathrm{NaCl}$ in the media was 
removed.

Gas chromatographic analysis of methionol. After static culture of a yeast strain in a medium at $30^{\circ} \mathrm{C}$ for 7 days, cells in the broth were removed by centrifugation. The cell-free broth $(3 \mathrm{ml})$ was mixed with an internal standard (dimethylmalonate $133 \mu \mathrm{g}$ ) and was saturated with $\mathrm{NaCl}$ $(\mathrm{g})$. Volatiles, including methionol, in the broth were extracted with methylacetate ( $\mathrm{m}$ ) by liquid-liquid extraction in a screw-capped tube for $20 \mathrm{~min}$ at $30^{\circ} \mathrm{C}$ using a shaker (Thermomixer TM121). The metylacetate layer was separated from the aqueous solution by centrifugation at $3500 \mathrm{rpm}$ for $10 \mathrm{~min}$ at $5^{\circ} \mathrm{C}$. Gas chromatography was done with a Shimadzu GC-14A chromatograph with a FID and a fused silica capillary column (Supelcowax 10, $15 \mathrm{~m}, 0.25 \mathrm{~mm}$ i.d. and $0.25 \mu \mathrm{m}$ f.t., Supelco, Inc.): oven temp., $50-220^{\circ} \mathrm{C}$, programmed $4^{\circ} \mathrm{C} / \mathrm{min}$; inlet temp., $240^{\circ} \mathrm{C}$; carrier gas, $\mathrm{He}(\mathrm{l} \mathrm{ml} / \mathrm{min})$; split rate, $1: 30$.

Extraction and assay of L-methionine and $S$-adenosylmethionine $(S A M)$. A yeast strain was cultured aerobically in a medium. Cells were harvested and washed twice with cold water. L-Methionine and SAM were extracted with hot water or cold perchloric acid $(1.5 \mathrm{~N})$ by the method of Chrest et al. ${ }^{8)}$ and measured by an amino acid analyzer (Hitachi Model 8500) or a high performance liquid chromatograph, ${ }^{9\}}$ respectively.

Preparation of crude extracts. After aerobic culture of a yeast strain in M.am-medium, cells were harvested, washed twice with ice-cold $0.05 \mathrm{M}$ potassium phosphate buffer $(\mathrm{pH} 7.5)$ by centrifugation at $4^{\circ} \mathrm{C}$, resuspended in the buffer, and disrupted with glass beads (diameter 0.25 to $0.5 \mathrm{~mm}$ ) in a grinder container for $3 \mathrm{~min}$ at $0^{\circ} \mathrm{C}$. The cell debris was removed by centrifugation at $18,000 \mathrm{rpm}$ for $20 \mathrm{~min}$ at $4^{\circ} \mathrm{C}$, and the supernatant was dialyzed against the buffer and used as a crude extract.

Enzyme assays. Some enzyme activities were measured with the crude extracts. SAM synthase (ATP-L-methionine-S-adenosyltransferase, EC 2.5,1.6) activity was assayed by the method of Peter et al. ${ }^{10)}$ Homocysteine synthase and cysteine synthase were assayed as described by Wiebers and Garner ${ }^{11)}$ at $30^{\circ} \mathrm{C}$ and the homocysteine or the cysteine formed was estimated by the method of Kredich and Tomkins. ${ }^{12)}$ Protein was measured by a Pierce protein assay kit using bovine serum albumin as the standard.

SAM uptake assay. Yeast was cultured statically in M.am-medium at $30^{\circ} \mathrm{C}$ to a cell density of 40 to $60 \mathrm{Klett}$ units. Cells were harvested by centrifugation at $30^{\circ} \mathrm{C}$ and resuspended in prewarmed M.am-medium to the cell density of about $100 \mathrm{Klett}$ units. After an additional culture at $30^{\circ} \mathrm{C}$ for $3 \mathrm{hr}$, a $2.45-\mathrm{ml}$ sample of the culture was transferred to a test tube containing $50-\mu \mathrm{l}$ of $0.5 \mathrm{~mm}$ ${ }^{14} \mathrm{C}-\mathrm{SAM}$ (specific activity, $10 \mu \mathrm{Ci} / \mu \mathrm{mol}$ ). The tube was then incubated at $30^{\circ} \mathrm{C}$, and $400-\mu \mathrm{l}$ of the culture were removed at 30 -sec intervals for $2.5 \mathrm{~min}$ and collected each on a membrane filter $(0.45-\mu \mathrm{m}$ pore diameter $)$. The filter was then washed three times with $4 \mathrm{ml}$ of ice-cold water, placed in $5 \mathrm{ml}$ of aqueous scintillation fluid (Filter-count, Packard Company), and the radioactivity was measured by a Beckman LS-9000 liquid scintillation counter. SAM retention on the washed filter was negligible in this method.

\section{Results and Discussion}

\section{Isolation of Ethionine-resistant mutants in $Z$. rouxii}

To isolate ethionine-resistant mutants, $Z$. rouxii $\mathrm{MA}^{\mathrm{r}} 1$ was mutagenized by $N$-methyl- $N^{\prime}$ nitro- $N$-nitrosoguanidine. Colonies grown on plates of the M.pro-medium supplemented with $2 \%$ agar and $100 \mu \mathrm{g} / \mathrm{ml}$ L-ethionine at $30^{\circ} \mathrm{C}$ for 7 days were selected. The parent $\mathrm{MA}^{\mathrm{r}} 1$ could not grow on the plate. These ethionineresistant mutants produced 1.3- to 9-fold methionol in MJ-medium, as compared with the parent strain. Especially, mutant M33 showed the largest production of methionol (about $108 \mathrm{ppm}$ ), hence the mutant was used throughout following experiments. Mutant M33 showed resistance also to $>0.01 \mathrm{~mm}$ of seleno-L-methionine, another analogue of methionine, in M.pro-medium. These results suggested that analogues of methionine were useful to select mutants hyper-producing methionol.

\section{Production of methionol in the parent and the mutant M33 strains \\ Parent $\mathrm{MA}^{\mathrm{r}} 1$ produced very large amounts}

Table I. EFFECTS OF L-METHIONINE OR SAM ON Production of Methionol by $Z$. rouxii Mutant

\begin{tabular}{lrcc}
\hline & \multicolumn{3}{c}{ Production of methionol (ppm) } \\
\cline { 2 - 4 } Strain & None $^{a}$ & $\begin{array}{c}\text { L-Methionine } \\
(20 \mathrm{mM})\end{array}$ & $\begin{array}{c}\text { SAM } \\
(10 \mathrm{mM})\end{array}$ \\
\hline Parent & 0.5 & 790.0 & $\mathrm{ND}^{b}$ \\
M33 & 30.0 & 785.0 & 25.0 \\
\hline
\end{tabular}

Each compound was added to M. am-medium. The cells were statically cultured at $30^{\circ} \mathrm{C}$ for 5 days in the medium.

a Nothing was added.

$b$ Not measured. 
of methionol in M.am-medium supplemented with $20 \mathrm{mM}$ L-methionine, but not in M.ammedium (Table I). This result suggested that the production of methionol by the parent strain was suppressed in a medium without methionine, although the strain potentially had a pathway for production of methionol from methionine. Mutant M33 produced a larger amount of methionol in M.am-medium than the parent, with no accumulation of methionine. This was also shown in minimum media containing L-glutamate or L-proline as a sole nitrogen source (data not shown). These results suggested that the mutant could produce methionol by de novo synthesis.

\section{Intracellular pool of methionine and methionol production}

The possibility of de novo synthesis of methionol by mutant M33 was examined by

Table II. EFFECTS OF L-METHIONINE ON Intracellular PoOl of Methionine AND SAM IN $Z$. rouxii MUTANT

\begin{tabular}{lccccc}
\hline & \multicolumn{2}{c}{ Methionine $^{a}$} & & \multicolumn{2}{c}{ SAM $^{a}$} \\
\cline { 5 - 6 } & Strain & $\begin{array}{c}\text { L-Methionine } \\
(20 \mathrm{mM})\end{array}$ & & None & $\begin{array}{c}\text { L-Methionine } \\
(20 \mathrm{mM})\end{array}$ \\
\hline Parent & 1.9 & 58.2 & & 0.96 & 31.44 \\
M33 & 9.3 & 81.7 & 1.35 & 2.23 \\
\hline
\end{tabular}

The cell were aerobically cultured at $30^{\circ} \mathrm{C}$ for 3 days in M. am-medium supplemented with or without Lmethionine.

a $\mu \mathrm{mol} / \mathrm{g}$ of dry cell weight.

$b$ Nothing was added. measurement of intracellular methionine. The pool of free methionine in the mutant cells grown in M.am-medium was about 5 times larger than that of the parental strain (Table II), so production of intracellular methionine through de novo synthesis was probably significantly increased in the mutant. In both the parent and the mutant strains, accumulation of a very large amount of intracellular methionine due to L-methionine supplementation in the M.am-medium was accompanied by significant hyper-production of methionol (Tables I, II). This result indicated that the hyperproduction of methionol by the mutant strain is due to the increase in intracellular methionine.

\section{Estimation of mutated enzyme in mutant M33}

At least three classes of methionine-hyperproducing mutant have been known among ethionine-resistant mutants of yeasts, according to the activity of SAM synthesis. ${ }^{8,13)}$ Therefore, the SAM pools in the cells grown in M.am-medium with or without addition of $20 \mathrm{~mm}$ L-methionine were measured (Table II). The pooled amount of SAM in the parent strain was greatly increased when the cells were cultured in methionine-supplemented medium, but that in the strain M33 was increased only slightly. Since SAM synthesis was reduced in the mutant, activity of the synthetic enzyme, SAM synthase, was measured (Table III). The activity of SAM synthase in mutant M33 was reduced to $45 \%$ of that in the parent strain. Therefore the deficiency of SAM synthase in

Table III. Repression of SAM Synthase, Cysteine Synthase and Homocysteine Synthase BY L-METHIONINE IN $Z$. rouxii MUTANT

\begin{tabular}{|c|c|c|c|c|}
\hline \multirow[b]{2}{*}{ Strain } & \multirow[b]{2}{*}{ Addition } & \multicolumn{3}{|c|}{ Specific activity (nmol/min/mg protein) } \\
\hline & & $\begin{array}{c}\text { SAM } \\
\text { synthase }\end{array}$ & $\begin{array}{l}\text { Cysteine } \\
\text { synthase }\end{array}$ & $\begin{array}{c}\text { Homocysteine } \\
\text { synthase }\end{array}$ \\
\hline \multirow[t]{2}{*}{ Parent } & None & 0.0380 & 1.92 & 5.06 \\
\hline & L-Methionine & 0.0137 & 0.90 & 0.05 \\
\hline \multirow[t]{2}{*}{ M33 } & None & 0.0171 & 2.01 & 6.65 \\
\hline & L-Methionine & 0.0074 & 2.17 & 7.65 \\
\hline
\end{tabular}

Enzyme activities were assayed with crude extracts prepared from cells grown in $\mathrm{M}$. am-medium supplemented with or without $20 \mathrm{~mm}$ L-methionine. 
Table IV. UPTAKE OF SAM By $Z$. rouxii MUTANT AND $S$, cerevisiae ATCC4098

\begin{tabular}{|c|c|c|}
\hline \multicolumn{2}{|l|}{ Strain } & $\begin{array}{l}\text { Specific activity of } \\
\text { SAM-uptake } \\
\text { (tomol } / \mathrm{min} / \mathrm{mg} \text { drycell weight }\end{array}$ \\
\hline \multirow[t]{2}{*}{ Z. rouxii } & Parent & 0.008 \\
\hline & M33 & 0.061 \\
\hline S. cerevisiae & ATCC4098 & 1.220 \\
\hline
\end{tabular}

Uptake of SAM $(0.005 \mathrm{~mm})$ was measured by the cells grown in $\mathrm{M}$. am-medium as described in the text.

mutant M33 was considered to be a reason for the accumulation of intracellular methionine.

To confirm the effects of a reduced SAM level in the methionine biosynthesis, activities of the two enzymes, homocysteine synthase and cysteine synthase, were assayed. The activities of both the enzymes in the parent strain were repressed by the addition of methionine to the medium, but not in mutant M33. Therefore it was suggested that the reduced SAM-level in mutant M33 induced derepression of the enzymes for methionine biosynthesis, although the mutant strain accumulated much intracellular methionine. Then, we examined the decrease in production of methionol due to repression of these derepressed enzymes by addition of SAM. Addition of SAM to M.am-medium could reduce the hyper-production of methionol, but the production was still large (Table I). Since it was doubted if mutant M33 could incorporate SAM, the uptake of SAM $(0.005 \mathrm{mM})$ by both the $Z$. rouxii strains were compared with that by a strain of $S$. cerevisiae, with which the uptake of SAM had been established ${ }^{8,14)}$ (Table IV). The SAMuptake by both the $Z$. rouxii strains was very much smaller than that by $S$. cerevisiae. These results suggested that the smail effect of SAM addition in the hyper-production of methionol by mutant M33 was caused by the deficiency of SAM uptake in the mutant strain.

Hayashibe et $a .^{4)}$ reported that the productivity of methionol in a medium containing methionine as a sole nitrogen source differed by yeast species and strains. We could not find, however, a large difference in methionol productivity among some soy-yeast species and strains in MJ-medium or M.ammedium (unpublished data). We have bred various yeast strains producing relatively large amounts of some higher alcohols such as isoamyl alcohol, isobutyl alcohol, 2-phenylethanol, or methionol. In the future, it will be feasible to proeduce a variety of flavor-rich soy sauces with these strains.

Acknowledgments. We acknowledge the technical assistance of Y. Shimaoka. We also wish to thank Dr. S. Sugiyama and Dr. H. Sekine for their encouragements.

\section{References}

1) S. Akabori and T. Kaneko, Nippon Kagaku Kaishi, 57, 832 (1936).

2) N. Nunomura, M. Sasaki, Y. Asao and T. Yokotuka, Agric. Biol. Chem., 40, 485 (1976).

3) S. Mori, N. Nunomura and M. Sasaki, Abstracts of Papers, the Annual Meeting of the Japan Society for Bioscience, Biotechnology, and Agrochemistry, Kyoto, April, 1982, p.36.

4) M. Hayashibe, S. Katoda, H. Owada, H. Yoshida, A. Katayose and T. Terashima, Hakkokogaku Kaishi, 48, 22 (1970).

5) T. Aoki and K. Uchida, Agric. Biol. Chem., 54, 273 (1990).

6) T. Aoki and K. Uchida, Abstracts of Papers, the Annual Meeting of the Japan Society for Bioscience, Biotechnology, and Agrochemistry, Tokyo, April, 1987 , p. 137.

7) C. Kanbe and K. Uchida, Nippon Nōgeikagaku Kaishi, 58, 487 (1984)

8) H. Chrest, Y. Surdin-Kerjan, J. Antoniewski and H. Robichon-Saulmajster, J. Bacteriol., 115, 1084 (1973).

9) N. Shiomi, H. Fukuda, H. Morikawa, Y. Fukuda and A. Kimura, Appl. Microbiol. Biotechnol., 29, 302 (1988).

10) K. C. Peter and L. C. Giulio, J. Biol. Chem., 252, 4506 (1977)

11) J. Wiebers and H. R. Garner, J. Biol. Chem., 242, 5644 (1967)

12) N. M. Kredich and G. N. Tomkins, J. Biol. Chem., 241, 4955 (1966).

13) E. Morzycka, D. Sawnor-Korszynska, A. Paszewski, J. Gral and K. Raczynska-Bonjanowska, Appl. Environ. Microb., 32, 125 (1976).

14) J. T. Murphy and K. D. Spence, J. Bacteriol., 109, 949 (1972). 